\title{
PENGARUH IKLIM ORGANISASI DAN PENGEMBANGAN KARIR TERHADAP KOMITMEN ORGANISASI DAN KEPUASAN KERJA
}

\author{
Imam Darmawan \\ Dosen Jurusan Ilmu Komunikasi, Fakultas Dakwah dan Komunikasi,UIN Suska Riau, \\ Jl. HR Soebrantas Km 15 Simpangbaru, Tampan, Pekanbaru 50275
}

\begin{abstract}
Abstrak
Sumber daya manusia (SDM) Media penyiaran telah memiliki kemampuan untuk menjadi mitra kerja yang dapat diandalkan, baik di pusat atau pun di daerah yang berupaya agar dapat meningkatkan kinerja karyawan dengan harapan apa yang menjadi tujuan media penyiaran akan tercapai. Adapun strategi yang ditempuh media penyiaran untuk meningkatkan kinerja karyawannya yaitu dengan memperhatikan kepuasan kerja dan komitmen organisasi sehingga dapat mendorong munculnya kreatifitas baru yang dapat memajukan lembaga ini. Agar hal ini dapat tercapai maka media penyiaran harus selalu memperhatikan iklim kerja dimana para karyawan melaksanakan tugasnya, serta memantau pengembangan karir setiap karyawannya.Tujuan penelitian ini adalah untuk mengetahui dan menganalisis pengaruh iklim organisasi terhadap komitmen organisasional dengan kepuasan kerja sebagai variabel intervening pada media penyiaran di Jl. Putri Hijau. Jenis penelitian ini adalah quantitative deskriptif. Populasi pada penelitian ini adalah seluruh karyawan pada media penyiaran berjumlah 211 orang dan teknik pengambilan sampel adalah dengan stratified random sampling berjumlah 139 karyawan. Dalam penelitian ini digunakan metode explanatory dan dalam pengumpulan data digunakan metode observasi, kuesioner, interview dan studi pustaka. Metode analisis data menggunakan metode deskriptif dan analisis stuktural equation modeling (SEM). Hasil penelitian menunjukan bahwa variabel pengembangan karir tidak berpengaruh signifikan terhadap kepuasan kerja pada media penyiaran.Variabel kepuasan kerja berpengaruh positif dan signifikan terhadap komitmen organisasional pada media penyiaran.Variabel Iklim organisasi berpengaruh negative dan tidak signifikan terhadap kepuasan kerja pada media penyiaran.Variabel kepuasan kerjaterhadap komitmen organisasi berpengaruh positive dan signifikan pada media penyiaran.Variabele iklim organisasi terhadap komitmen orga nisasi tidak berpengaruh dan tidak signifikani Pada Media Penyiaran.Variabel pengembangan karir terhadap komitmen organisasi tidak berpengaruh signifikanpada media penyiaran.
\end{abstract}

Kata kunci: Iklim Organisasi, Pengembangan Karir, Kepuasan Kerja dan Komitmen Organisasi 


\section{A. PENDAHULUAN}

\section{Latar belakang}

Pada saat ini media massa memiliki peran yang sangat penting bagi masyarakat. Peran tersebut terlihat dari kebutuhan masyarakat akan informasi. Media yang masih menjadi pilihan bagi masyarakat untuk memperoleh informasi adalah televisi.Melalui televisi, masyarakat dengan mudah dan cepat dapat mengetahui informasi dari dalam maupun luar negeri.Selain itu, media televisi merupakan media yang penyampaian informasinya melalui gambar dan suara sehingga penyampaian informasinya lebih jelas dan mudah dipahami oleh masyarakat dimanapun dan kapanpun berada.Dengan banyaknya stasiun televisi, masyarakat dapat memilih tayangan yang mereka inginkan tanpa harus keluar dari rumah atau tempat tinggal mereka.

Untuk meningkatkan peranan stasiun televisi agar dapat mewujudkan masyarakat intelektual, cerdas dan berwawasan luas maka perlu adanya dukungan oleh berbagai stasiun televisi.Dukungan tersebut dapat berupa pemberian informasi yang aktual dan terpercaya untuk kehidupan yang lebih baik.

Dalam persaingan pertelevisian saat ini, sumber daya manusia (SDM) media penyiaran harus mampu untuk menjadi mitra kerja yang dapat diandalkan, baik oleh para pemimpin di pusat atau pun di daerah dan selalu berusaha untuk meningkatkan kinerja karyawan dengan harapan apa yang menjadi tujuan media penyiaran akan tercapai. Berbagai cara selalu ditempuh media penyiaran dalam meningkatkan kinerja karyawannya, misalnya dengan memperhatikan kepuasan kerja, menumbuh kembangkan komitmen organisasi sehingga dapat mendorong munculnya kreatifitaskreatifitas baru yang dapat memajukan lembaga tersebut. Agar hal ini dapat tercapai maka media penyiaran harus selalu memperhatikan iklim kerja dimana karyawan melaksanakan tugasnya, serta memantau pengembangan karir setiap karyawannya.

Karyawan media penyiaran merupakan pegawai negeri sipil pusat dibawah kementerian informasi dan komunikasi yang berupaya untuk meningkatkan kualitas Sumber Daya Manusia yang bekerja di lembaga ini.Seperti undangundang kepegawaian sebagai berikut:

1. Pasal 12 dan Pasal 20 UU No. 43 tahun 1999 antara lain mengamanatkan bahwa pembinaan dilakukan berdasarkan sistem prestasi kerja dan sistem karir untuk

2. Pasal 9 angka 12 dan pasal 10 angka 10 No 53 tahun 2010 tentang disiplin PNS dinyatakan apabila pencapaian sasaran kerja PNS (SKP) pada akhir tahun hanya mencapai antara $25 \%$ s.d $50 \%$ maka dikenakan hukuman sedang dan yang SKP nya dibawah $25 \%$ dikenakan hukuman berat.

Namun, pada pelaksanaannya tidak sedikit pegawai pemerintahan yang belum dan bahkan tidak berkeinginan sama sekali menunjukkan prestasinya dalam bekerja. Untuk meningkatkan daya saing secara nasional dan internasional media penyiaran Sumut perlu memperhatikan kembali kepuasan kerja dan komitmen organisasi secara menyeluruh dengan melihat hal apa saja yang dapat mempengaruhi kepuasan dan komitmen organisasi pada media penyiaran.

Menurut laporan calon pegawai negeri sipil dan ternyata diketahui bahwa pendidikan SLTA merupakan karyawan mayoritaspada media penyiaran. Padahal untuk memenuhi jabatan tertentu perusahaan sebaiknya memperoleh karyawan dengan pendidikan sesuai dengan jabatan.Khususnya jabatan-jabatan struktural Kepala Bagian Keuangan, diutamakan karyawan yang telah berpengalaman.

Tahun 2011 pemerintah telah membuat peraturan menteri (Permen) No.22 Tahun 2011 yang mengatur migrasi penyiaran dari 
sistem analog ke sistem digital, di mana dengan permen ini diharapkan Indonesia khususnya stasiun televisi dapat mengikuti perkembangan zaman. Oleh karena itu, untuk dapat mencapai era digitalisasi tersebut, maka pegawai yang berada di lingkungan media penyiaran dituntut untuk memiliki kualitas diri yang baik dan kreatifitas yang lebih besar agar dapat menyampaikan konten yang telah ditentukan pemerintah menjadi tayangan yang menarik dan diminati masyarakat luas. Untuk bisa mencapai kualitas tersebut, maka pemerintah khususnya pimpinan media penyiaran harus dapat meningkatkan kepuasan kerja dan komitmen berorganisasi seluruh karyawannya dengan cara melihat hal-hal apa saja yang dapat mempengaruhi kepuasan kerja dan komitmen organisasi karyawan di media penyiaran.

\section{Rumusan masalah}

Adapun banyak rumusan penelitian adalah sebagai berikut:

1. Bagaimana pengaruh langsung iklim organisasi terhadap komitmen organisasi pada media penyiaran?

2. Bagaimana pengaruh langsung pengembangan karir terhadap komitmen organisasi pada media penyiaran?

3. Bagaimana pengaruh langsung iklim organisasi terhadap kepuasan kerja pada media penyiaran?

4. Bagaimana pengaruh pengembangan karir terhadap kepuasan kerja pada media penyiaran?

5. Bagaimana pengaruh kepuasan kerja terhadap komitmen organisasi pada media penyiaran?

\section{Tujuan Penelitian}

Berdasarkan perumusan masalah diatas, penelitian ini ditujukan:

1. Untuk menganalisis dan mengetahui pengaruh iklim organisasi terhadap komitmen organisasi pada media penyiaran
2. Untuk menganalisis dan mengetahui pengaruh pengembangan karir terhadap komitmen organisasi

3. Untuk menganalis dan mengetahui pengaruh pengembangan karir terhadap komitmen organisasi pada media penyiaran.

4. Untuk mengetahui dan menganalisis pengaruh Iklim organisasi terhadap komitmen organisasi pada media penyiaran

5. Untuk mengetahui dan menganalis pengaruh kepuasan kerja terhadap komitmen organisasi pada media penyiaran.

\section{Manfaat penelitian}

1. Bagi Media Penyiaran

Memberikan informasi mengenai tingkat kepuasan kerja karyawan dan merekomendasikanupaya

meningkatkankomitmen organisasional dalam bingkai iklim organisasi dan career development

2. Bagi para pembaca

Mengembangkan ilmu pengetahuan tentang ilmu manajemen sumber daya manusia. Selain itu hasil penelitian ini dapat dijadikan sebagai referensi bagi peneliti lainnya dengan topik serupa di masa yang akan datang.

\section{TINJAUAN PUSTAKA}

\section{Iklim Organisasi}

Elsa (2013) menyatakan bahwa iklim organisasi merupakan bangunan dasar pekerjaan dan aturan-aturan yang ada pada organisasi.Kurt lewin (2008) ahli manajemen sumber daya manusia yang menemukan istilah iklim organisasi menggunakan istilah iklim psikologi.Menurut Litwin dan Stringer (dalam Wirawan, 2008:12) iklim organisasi adalah serangkaian lingkungan, budaya, suasana, situasi, pola lapangan, pola prilaku 
dan keadaan atau kondisi.Menurut wirawan (2012) mengatakan istilah iklim organisasi diperkenalkan istilah iklim psikologikal climate. Kemudian istilah iklim organisasi dipakai oleh litwin dan tagiuri (2008) yang mengemukakan sejumlah istilah dari prilaku dalam hubungan dengan latar dan tempat dimana prilaku terjadi: lingkungan pergaulan, budaya, situasi, pola lapangan dan pola prilaku.

\section{Pengembangan Karir}

Pengembangan karir adalah suatu peningkatan pada jalur karir atau pada pola karir seseorang di tempat karyawan bekerja atau di organisasi yang bersangkutan (Martoyo, 1998).Keberhasilan pengembangan karir seseorang tidak terlepas dari kemampuan berkomunikasi maupun kemampuan beradaptasi didalam organisasi (Wirawan, 2012).

Hasil penelitian Wijanarka (2000) menjelaskan bahwa sistem pengembangan atau rencana karir didalam suatu organisasi ditentukan oleh Penilaian Prestasi Kerja (DP3).Namun dari berbagai kesimpulan diperoleh bahwa pengembangan karir pada seluruh level PNS masih belum memberikan penilaian secara objektif dan terukur.Implikasi dari hal tersebut adalah pekerjaan, sehingga kinerja sesungguhnya tidak dapat diketahui. Maka, berdasarkan hasil penelitian tersebut dapat diketahui bahwa seorang PNS tidak dapat menggantungkan masa depan karirnya dengan mengandalkan hasil penilaian yang diterapkan oleh instansi.

\section{Kepuasan Kerja}

Karyawan adalah kekayaan utama bagi setiap perusahaan mereka menjadi pelaksana, perencana dan pengendali yang selalu berperan aktif dalam mewujudkan tujuan perusahaan.Karyawan menjadi pelaku yang menunjang tercapainya tujuan, mempunyai pikiran, perasaan dan keinginan yang dapat mempengaruhi sikap-sikapnya terhadap pekerjaannya.Sikap ini menentukan prestasi kerja, dedikasi dan kecintaanterhadap pekerjaanyang dibebankan kepadanya. Sikapsikap positif harus dibina, sedangkan sikapsikap negatif sebaiknya dihindari.Sikap-sikap karyawan dikenal dengan kepuasan kerja, stress kerja dan frustasi yang ditimbulkan pekerjaan, peralatan, lingkungan kebutuhan dan sebagainya.Kepuasan kerja karyawan harus diciptakan sebaik-baiknya.

Sebagai evaluasi pribadi dari kondisi saat ini dari pekerjaan atau hasil yang timbul sebagai akibat dari memiliki pekerjaan.Sampan, Rieger dan Roodt (2002) tampaknya setuju dengan definisi ini, menyatakan bahwa kepuasan kerja mengacu pada persepsi dan evaluasi dari pekerjaan.Sempane, Rieger dan Roodt (2002) tampaknya setuju dengan definisi ini, menyatakan bahwa kepuasan kerja mengacu pada persepsi dan evaluasi individu dari pekerjaan.Menurut para penulis ini, persepsi individu dipengaruhi oleh orang-orang atas dasar faktor-faktor yang penting bagi mereka.Meskipun definisi kepuasan kerja yang bervariasi, umumnya dianggap sebagai sikap atau perasaan yang dimiliki seseorang tentang pekerjaaan seseorang yang positif atau negatif.

\section{KESIMPULAN DAN SARAN Kesimpulan}

Berdasarkan hasil penelitian dan pembahasan pada bab sebelumnya maka dapat disimpulkan beberapa hal sebagai berikut:

1. Pengembangan karir secara langsung berpengaruh tidak signifikan terhadap kepuasan kerja pegawai media penyiaran

2. Iklim Organisasi secara langsung berpengaruh negatif signifikan terhadap kepuasan kerja pegawai media penyiaran. 
3. Kepuasan Kerja secara langsung berpengaruh positif signifikan terhadap komitmen Organisasi pegawai media penyiaran

4. Pengembangan Karir secara langsung berpengaruh tidak signifikan terhadap komitmen organisasi pegawai media penyiaran

5. Iklim Organisasi secara langsungtidak berpengaruh signifikan terhadap komitmen organisasi pegawai media penyiaran.

\section{Saran}

Berdasarkan penelitian yang telah dilakukan di media penyiaran tentang pengaruh pengembangan karir dan iklim organisasi terhadap komitmen organisasi melalui kepuasan kerja, maka saran dari peneliti adalah sebagai berikut:

1. Diharapkan media penyiaran mengevaluasi dan menyesuaikan pelatihan dan pengembangan sesuai dengan masalah yang dihadapi sehingga dapat menyelesaikan pekerjaan secara mandiri walaupun karyawan yang ada adalah PNS yang sudah memiliki kriteria karir yang jelas.

2. Diharapkan promosi, mutasi dan kekerabatan karyawan lebih ditingkatkan dan dipertahankan baik untuk mempertahankan komitmen dan beberapa dimensi lainnya yang teridiri dari normative comitment, continuance comitment dan affective commitment.

3. Diharapkan media penyiaran memberikan Studi dan menciptakan iklim organisasi yang lebih kondusif .

4. Diharapkan pimpinan perusahaan media penyiaran mengevaluasi dan meningkatkan rencana, visi dan misi perusahaan dengan menyesuaikan kemampuan SDM pada perusahaan.

\section{DAFTAR KEPUSTAKAAN}

Chienyu, 2001. Knowledge sharing organizational climate and innovative behaviour: A cross-level analysis of effects. Vol. 41 No. 3.

Dessler, Gary, 1986. Manajemen Personalia: Teknik dan Konsep Modern. Edisi Ketiga. Penerbit Erlangga. Jakarta.

Davis, Kelly. 2001. Students' Perceptions of Rewards for Academic Performance by Parents and Teachers: Relations With Achievement and Motivation in College.Vol.7 No 21.

Elsa Pena. Assessing Organizational Climate: Psychometric Properties of The CLIOR 847.Vol 3

Galanou Eka Terini. 2011. The Effect Of Reward System On Job Satisfaction In An Organizational Chart Of Four Hierarchical Levels: A Qualitative Study. 8: 485-519.

Gene. 2011. The relationship of engagement and job satisfaction in working samples. Vol 145 No.1.

Gene Alarcon. 2001. The relationship of engagement, job satisfaction and turn over intentensions. Vol.27 No 1

Georgeta. 2001. Motivation And Loyalty In Educational Organization. Vol 1.

Hadi, S.Structural Equation Modeling dengan Lisrel, Edisi Pertama, Yogyakarta

Margono. 2015. Analisis produktivitas dan ketenaga kerjaan: suatu pendekatan makro-mikro ekonomi. Disertasi. Program Pasca Sarjana. Institut Pertanian Bogor, Bogor.

Meuthia, F., 2012. Pengaruh employee engagement terhadap semangat kerja pada PT. Perkebunan X Medan. Tesis. Program Pascasarjana. Universitas Sumatera Utara. Medan

Mariami, I. 2013. Pengaruh motivasi dan Pengembangan Karir terhadap Loyalitas Kerja Karyawan dengan Kepuasan Kerja Sebagai Variabel Interventing Pada Hotel Inna Dharma 
Deli. Tesis. Program Pasca Sarjana. Universitas Sumatera Utara. Medan.

Sulstywati, N. 2012. Dampak Investasi Sumber Daya Manusia terhadap Perekonomian dan Kesejahteraan Masyarakat di Jawa Tengah. Disertasi. Program Pasca Sarjana. Institut Pertanian Bogor. Bogor

Suhaemi, E. 2013. Analisis Pengaruh Kepuasan Kerja, Komitmen Organisasi Dan Kecerdasan Emosional Terhadap Kinerja Karyawan Kantor Pusat Operasional (KPO) PT. Bank Aceh Banda Aceh. Tesis. Universitas Sumatera Utara. Medan.

Marchell, 2012. Pengaruh Kepuasan Kerja dan Loyalitas Kerja Terhadap Organizational Citizenship Behaviour pada Karyawan PT. Surya Timur Sakti Jatim. Vol 1, No 3 933-97.

Monia L. Castro. 2012. The Relationship Between Organizational Clime And Job Satisfaction In A South African Information And Technology Organization. Vol 36, No 36 (2012):01-09.

Marx, Ivo. 2012. The impact of Finance Reward Contingencies On Cognitive Function Profile in Adult ADHD. Vol 8 No 8 (2012):1-10.

Peter Langford. 2006. Measuring Organisational Climate and Employee Engagement: Evidence for a 7 ps Model of Work Practices and Outcomes. Vol 61 (2006): 185-198.

Purnama, Ayu. 2003. Peran Gaya Kepemimpinan Dan System Pengendalian Di Perusahaan Keluarga. PT. Sus Surabaya.Vol 2 (2003): 01-17.

Susanty, E. 2005. Pengaruh Iklim organisasi terhadap kepuasan kerja dan komitmen karyawan pada Universitas Terbuka (UT) Bogor: Pasca Sarjana Institut Pertanian Bogor Tesis.
Shwu-ru. 2001. Organizational Climate, Organizational Commitmen and Intention to Leave Amongs Hospitals Nurses in Taiwan. Vol 19 no. 1

Seimenis, Loanis. 2000. Performance Management and Reward. Vol 2 No. 9

Sousa, Cristina. 2001. Innovation, creativity and reward practices in academy spinoffs: the case of the IST Spin-off community. Vol 12 No.4

Sushi Chandra Badoni. 2001. A Study Of The Organizational Climate In Relation To Job Satisfaction Of Senior Secondary School Teachers Of Haridwar District in Uttarakhand. Vol 1 No.1

Valentine, 2000. Organizational Climate Diagnosis-Connections With Employee Organization fit. Case study. Vol.1 No.1

\section{Internet}

http://www.kopertis12.or.id/2014/01/23/unda ng-undangan-nomor-5-tahun-2014tentang-aparatur-sipilnegara.html\#sthash.WepfJrpJ.dpu 